\title{
Office of Assistant Secretary of Health
}

National Cancer Institute

\section{Source}

National Cancer Institute. Office of Assistant Secretary of Health. NCI Thesaurus. Code C39481.

The Office of Assistant Secretary of Health (OASH) is a component of the Department of Health and Human Services. OASH administers and exercises oversight responsibility for the Public Health Service (PHS) and its component health agencies. The PHS is comprised of all agency divisions of HHS and the Commissioned Corps, uniformed health professionals who serve at HHS and other federal agencies. OASH provides funds for research and public health programs. 